\title{
Ecological similarities between two Mediterranean wetlands: Sidi Boughaba (North-West Morocco) and the Doñana National Park (South-West Spain)
}

\author{
Najat ELKHIATI, ${ }^{1}$ Mohamed RAMDANI, ${ }^{2}$ José L. ESPINAR, ${ }^{3}$ Khalid FAHD,${ }^{4}$ Laura SERRANO ${ }^{5 *}$ \\ ${ }^{1}$ Département de Biologie, Université Hassan II, Faculté des Sciences Aïn Chock, Casablanca; ${ }^{2}$ Département de Zoologie et Ecologie \\ Animale, Université Mohammed V, Institut Scientifique, BP 703 Rabat, Morocco; ${ }^{3}$ Doñana Biological Station (CSIC), Sevilla; ${ }^{4}$ Centro \\ de Nuevas Tecnologías del Agua, Sevilla; ${ }^{5}$ Department of Plant Biology and Ecology, University of Sevilla, P.O. Box 1095, 41080- \\ Sevilla, Spain \\ *Corresponding author: serrano@us.es
}

\begin{abstract}
Addressing the underlying common processes within aquatic systems located in the same geographical region has long been used as a tool for the advancement of limnology. A limnological study of the Merja Sidi Boughaba in 2009 has shown that there are many common features between the physico-chemical and biological conditions of this site and previous data reported from some of the wetlands of the Doñana National Park (South-West Spain). Both are Ramsar sites located on extensive dune systems of the Atlantic coast with a Mediterranean climate. They have a common palaeoenvironmental history that is largely responsible for their similar hydrology and water composition. Oceanic influence has probably produced a slight disproportion of $\mathrm{Mg}^{2+}$ over $\mathrm{Ca}^{2+}$ through airborne sea salt deposition and the surface evaporation of groundwater feeding these wetlands during annual flood and drought cycles. The wide spectrum of environmental conditions encountered in the Doñana wetlands is epitomised by the Merja Sidi Boughaba, where water and sediment gradually change in the same water body from north to south: from humic-coloured waters and a sandy substrate to a calcium-rich substrate with turbid and silted waters which eventually dry out. As a consequence, the community of submersed macrophytes is very rich and dominated by dense charophyte beds. The high primary production coupled with high biodiversity found in the Merja Sidi Boughaba is also shared by the Doñana wetlands. The high conservation status of both sites enables a useful comparison to be made of the water quality of shallow aquatic systems at a regional scale which, contrary to the trophic classifications developed for deep stratified lakes in temperate regions, is not based on regressions between the concentrations of chlorophyll and total phosphorus (Tot-P) but on the proportions of dissolved and particulate P pools. In these Mediterranean sites, nutrients are more efficiently recycled through the sediment (whether deposited at the bottom or suspended in the water column) while seasonal fluctuations of the water level are stronger than in deep stratified lakes and, hence, no significant correlation was found between chlorophyll and either total or particulate P in our study.
\end{abstract}

Key words: merja, pond, water quality assessment, macrophytes, charophytes, nutrients.

Received: October 2012. Accepted: January 2013.

\section{INTRODUCTION}

Regional limnological studies have long promoted the advancement of limnology. The comparison of common features among different water bodies within one geographical area has proved to be a powerful tool in addressing many underlying common processes (Horne and Goldman, 1994). Many wetlands located along the NorthWestern coast of Morocco are important stopovers for wildfowl on the migratory route that connects Africa and Europe, and they therefore have long been known to waterfowl researchers in South-West Spain (Green et al., 2002). However, the scarcity of limnological studies from North African wetlands has been considered a serious hindrance to the advancement of a regional Mediterranean limnology (Álvarez-Cobelas et al., 2005), as few publications have aimed at the characterisation and comparison of several wetlands in North Africa (Flower, 2001; Ramdani et al., 2001, 2009).
There are several local terms used to categorise the aquatic systems of North Africa. The Arabic term daya indicates a shallow natural or sometimes artificial depression (usually $<1.5 \mathrm{~m}$ deep) that contains water for at least some part of the year, while the term merja indicates a shallow surface sheet of water with extensive mud flats. In NorthWest Morocco, a daya generally designates a pond, while a merja refers to an extensive wetland such as those found in large depressions on the landward side of coastal dune systems, which are characterised by extensive stands of emergent plants, including Phragmites communis, Typha angustifolia, Juncus maritimus, Juncus acutus and Scirpus (Chergui et al., 1999; Ramdani et al., 2009). The wide range of climatic and altitudinal conditions across Morocco prevents making further generalisations, other than for the length of the aquatic phase (or hydroperiod): a daya is usually a seasonal site, whereas water in a merja is often brackish and more permanent due to its proximity to a shallow water table (Ramdani et al., 2009). 
Despite large differences in hydrology, some authors have attempted to compare the water quality of several North African coastal lagoons and shallow lakes (Fathi et al., 2001; Flower, 2001; Ramdani et al., 2001; Green et al., 2002). However, the application of a trophic classification developed for deep stratified lakes (OECD, 1982) has resulted in the assumption of a poor water quality for many of these systems. In temperate regions, total phosphorus (Tot-P) concentration is often used as a surrogate variable for the potential lake productivity of shallow water bodies (Søndergaard et al., 2005), although trophic thresholds based on regressions between the concentration of chlorophyll and Tot-P are not useful in the most shallow aquatic systems due to their more efficient recycling of nutrients through the sediment (Golterman, 2004). Additionally, the wide hydrological fluctuations encountered in Mediterranean shallow aquatic systems have a strong concentrative effect on all suspended and dissolved elements, thus altering chlorophyll responses to Tot-P (Álvarez-Cobelas et al., 2005; Ludovisi and Gaino, 2010; Papastergiadou et al., 2010). Although shallow lakes are acknowledged to widely differ across large scales due to regional differences in morphometry, geology, climate and hydrological regimes (Nõges et al., 2003; Moss et al., 2004), the relationship between the concentration of chlorophyll and Tot-P is assumed to be generally meaningful for lakes, and few authors have claimed that very different lake types require more sophisticated indexes in order to take into account the different trophic or biogenic potential of each lake (Rossaro et al., 2006). In the context of Mediterranean shallow aquatic systems, water quality assessment would require the differentiation of anthropogenic eutrophication against a background of natural eutrophy, where natural eutrophy refers to ecosystems with a high trophic status due to intrinsic features of morphometry, lithology, latitude or climate. Golterman (2004) has established that the bioavailability of $\mathrm{P}$ in a water body is controlled by the P-binding capacity of the sediment, and that the annual concentration of dissolved inorganic phosphate (i-P) will grow exponentially in a system as the sediment binding capacity is gradually saturated under a constant external P-load. Therefore, we will use the proportion of i-P over Tot-P in the water during the growing season to assess whether a system is still able to control the bioavailability of $\mathrm{P}$ through both its biomass uptake and sediment-binding capacity or, in contrast, whether an excess of i-P concentration has been built up in the water due to the saturation of these processes under the effect of a strong anthropogenic eutrophication.

A joint project to study the limnology of the Merja Sidi Boughaba (North-West Morocco) during 2009 has allowed some key physico-chemical and biological variables to be compared with previous data reported from the Doñana wetlands (South-West Spain). The reason for making this comparison is that both areas share a common geological origin. The Guadalquivir river basin and the El Gharb basin (Fig. 1) developed as two fold-and-thrust belts composed of the Triassic to Neogene deposits of the South Iberian and Maghrebian palaeomargins, respectively, which developed in front of the same orogenic system: the Gibraltar arc, which extends north to south from the Betic to the Rif mountain ranges (Crespo-Blanc and Frizon de Lamotte, 2006). The Doñana region was formed within the Lower Guadalquivir river basin during the Quaternary age, when the estuary of the Guadalquivir river was enlarged and reshaped by the formation of sandy spits through several dune generations after the last postglacial transgression (Rodríguez, 2006). The El Gharb basin (North-West Morocco) developed in a parallel way during the Quaternary age, until an extensive sand dune system formed at the seaward margin of the estuary of the Sebou river (Barbieri and Ori, 2000).

The comparison between both the aforementioned wetland areas is meaningful for several other reasons. Firstly, both areas share a Mediterranean sub-humid climate and the geographical similarity of being located within the catchments of large rivers draining into the Atlantic ocean: the Sebou river (Oued Sebou) and the Guadalquivir (al-wadi al-Kabir in Arabic) are long rivers (over 500 and $700 \mathrm{~km}$, respectively) with a permanent, though irregular, flow and a high sediment load (Chergui et al., 1999). Secondly, both areas share a common palaeogeography (Barbieri and Ori, 2000), which is the reason for their coastal location and relatively young age. Thirdly, both areas are located along a major migration route between Africa and Europe: the capacity of migratory birds for transporting propagules of plants and invertebrates has been widely described in the literature, and bird-mediated transport is an important mechanism of long-term dispersal, particularly in sites with a high transit of waterbirds, such as this Moroccan wetland (Green et al., 2002). Fourthly, the high conservation status of these wetlands (both are Ramsar sites) warrants a meaningful comparison of the water quality of shallow aquatic systems at a regional scale. Finally, we question whether the high biodiversity coupled with high trophic status is not a unique characteristic but a feature of well-preserved water bodies in the Mediterranean region.

\section{METHODS}

\section{Study site description}

The Merja Sidi Boughaba is the only permanent shallow lake $(<3 \mathrm{~m}$ deep) by the estuary of the Sebou river (Fig. 2). The lake lies in a $\sim 6 \mathrm{~km}$ long depression that separates the coastal mobile dunes (20-30 m high) and a rim of fossilised dunes ( $\sim 50 \mathrm{~m}$ high) on the east side. The slopes of this 650-ha depression reach an elevation of 77 
$\mathrm{m}$ and present a substrate described as aeolian sands with a different degree of organic matter deposition, while a combination of silt, clay and organic matter dominates in the bottom of the basin, which lies at an approximate elevation of $3 \mathrm{~m}$ amsl (Cherkauoi and Bouchafra, 2003). A small seasonal daya, adjacent to the Merja Sidi Boughaba, is located in the upper part of the lake basin at its northern rim (Fig. 2). During heavy floods, the surface water of this daya flows downward into the merja. The whole 650ha depression, including both the daya and the merja, was established as a National Natural Reserve of Sidi Boughaba in 1975 and was designated as a site of international importance by the Ramsar Convention in 1980 . A dense forest of Juniperus phoenicea, Olea europaea, Pistacia lentiscus and Myrthus communis grows on the slopes, thickets of Populus alba encircle the southwestern lake shore (Ramdani et al., 2001) and Ammophila arenaria grows on the mobile dunes (Cherkaoui and Bouchafra, 2003). The lake basin is presently disconnected from both the river and the ocean (Ramdani et al., 2001), so lake water depends on rainfall and groundwater which flow towards the ocean from the Mamora aquifer in a northwestern direction (Zouhri et al., 2004). This aquifer is generally unconfined and rests on a MioPliocene marine blue marl basement, which increases in thickness towards the Atlantic Ocean (60-90 m deep) and is recharged by rainfall infiltration through the very permeable sand and gravels (Zouhri et al., 2004).

\section{The Doñana wetlands}

The Doñana National Park (about 54,000 ha) includes three main landscapes (Fig. 3): i) a silty-clay floodplain (about 23,000 ha) with a seasonally flooded marshland mainly fed by rainfall and the overflow of streams and rivers; ii) an area of sand dunes fixed by the vegetation; and iii) an active sand dune system with several dune fronts (up to $32 \mathrm{~m}$ high, $15 \mathrm{~km}$ long and $3 \mathrm{~km}$ wide) running parallel to the coast line in a South-West/North-East direction (García-Novo and Marín, 2006). The ecotone or border between the two main units (marshland and sand dunes) also forms a distinct landscape of seasonal wet meadows (Fig. 3). The coastal dune stretch of Doñana is the largest in the gulf of Cádiz (Rodríguez, 2006). The

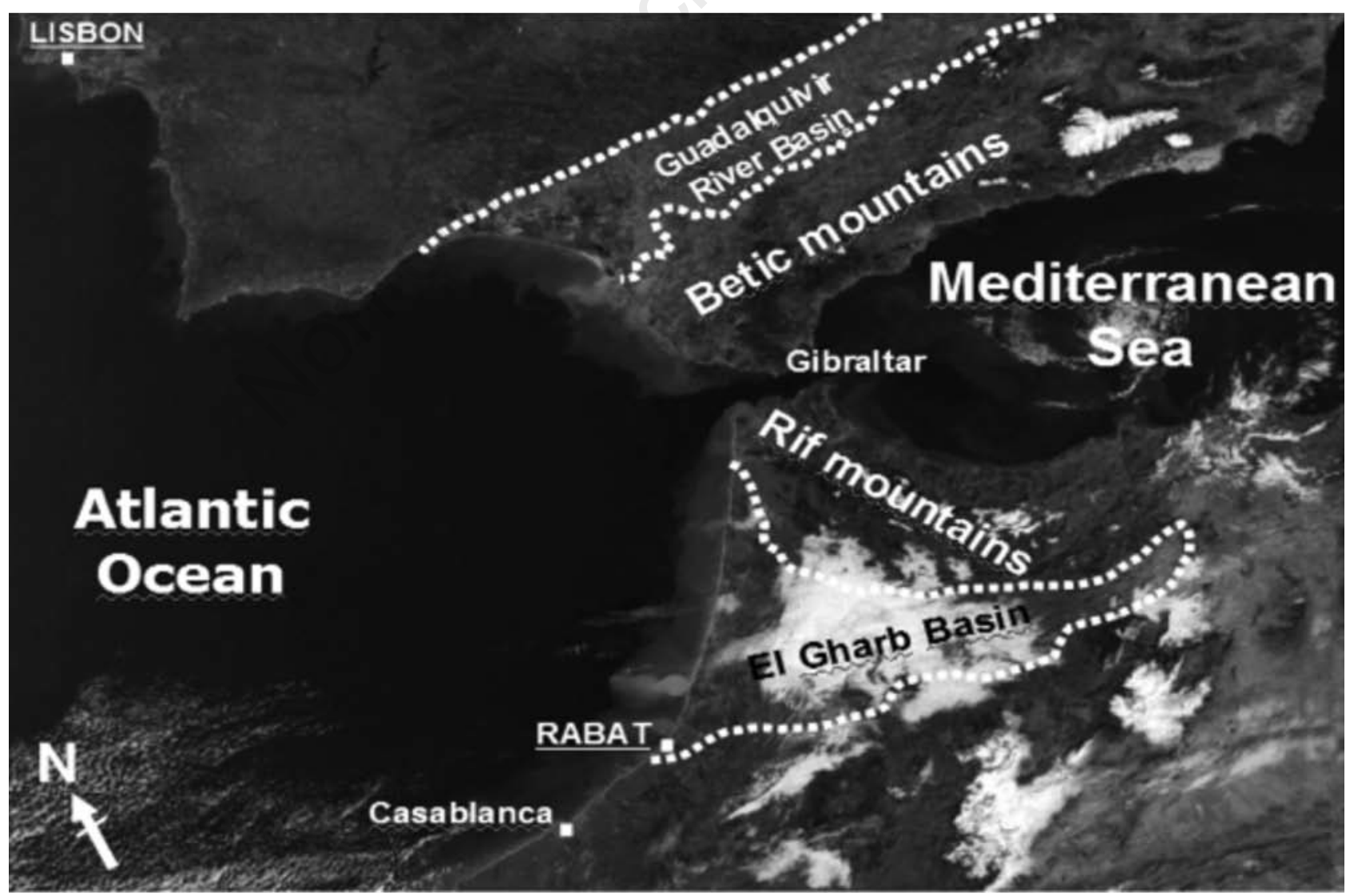

Fig. 1. Satellite photograph of the South-Western coast of Spain and North-Western coast of Morocco, indicating the location of Guadalquivir river basin and El Gharb basin. 
depth of the sand deposits varies from over $100 \mathrm{~m}$ on the coast to barely $10 \mathrm{~m}$ at the northern edge of the park. This extensive Holocene sand mantle lies on impermeable marine blue marls and holds an unconfined aquifer (with a shallow water table and several flow systems), in which groundwater recharge is produced by rainfall infiltration at an estimated rate of $200 \mathrm{~mm} \mathrm{y}^{-1}$ (Llamas, 1990). Thousands of small temporary ponds, which are fed by rainfall, runoff and a shallow water table are found on depressions amid the sands. They range widely in size, from temporary rain puddles to shallow lakes, and in hydroperiod, from days to decades (Serrano et al., 2006). They are fed by a combination of direct rainfall, runoff and the discharge of this shallow water table, but the processes by which they are fed by groundwater is relatively complex due to changes in recharge and topographic boundaries that modify their connection to different aquifer flow systems over time (Sacks et al., 1992). The data presented here has been gathered from those ponds fringing the active dunes that can hold water for longer periods, such as Santa Olalla, Dulce, Taraje and Las Verdes ponds (Fig. 3). The complete list of ponds and their locations can be found elsewhere (Serrano et al., 2006). The largest pond in Doñana - Santa Olalla pond - only incorporates a maximum flooded basin of about 100 ha at an elevation of 4 $\mathrm{m}$ amsl Although the groundwater discharge into these ponds can be complex, the ponds have no surface or groundwater connection to the sea and have been reported

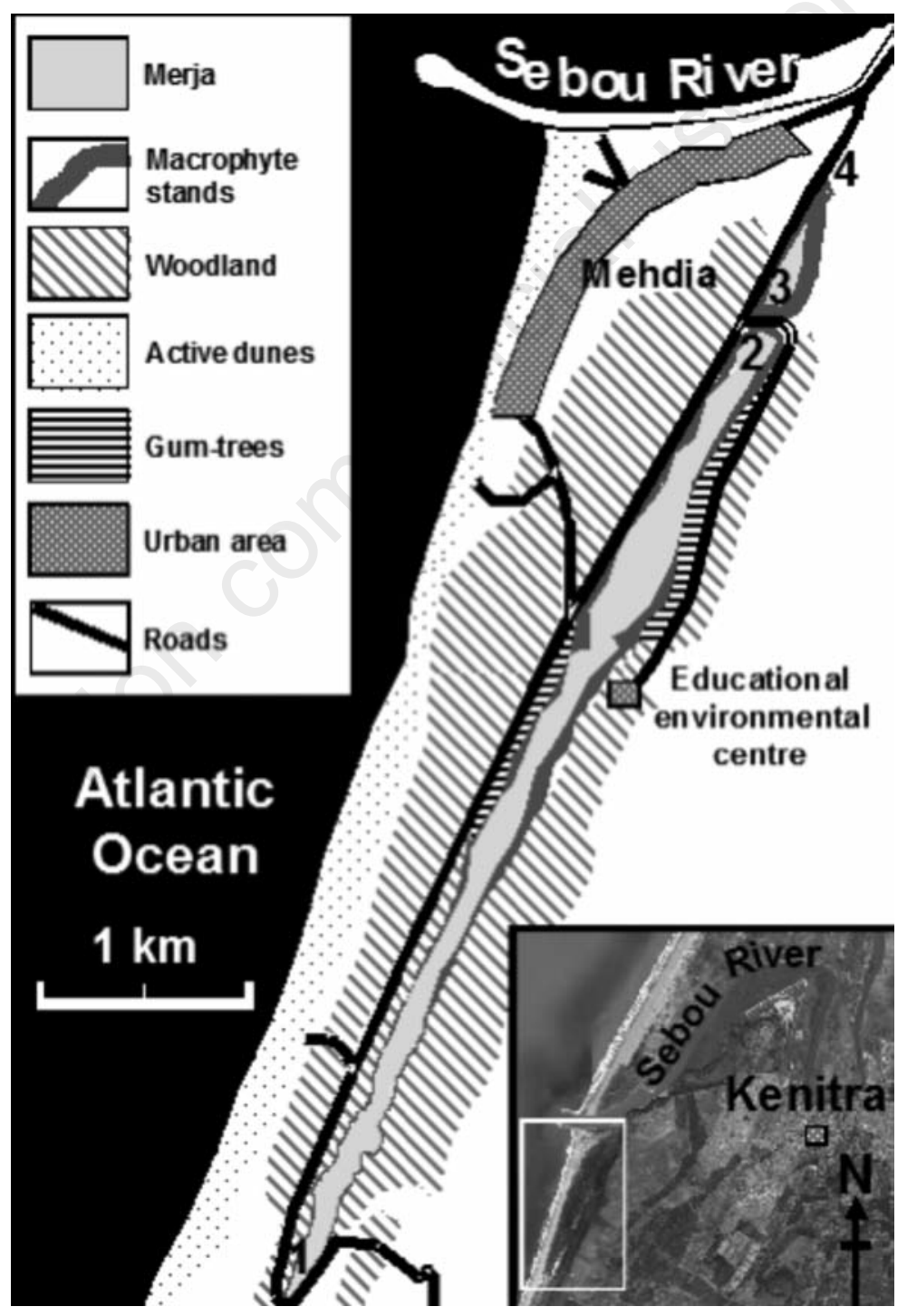

Fig. 2. Map of the National Nature Reserve of Sidi Boughaba, situated by the estuary of the Sebou river near the city of Kenitra (North-West Morocco). Three sampling stations were located within the merja (1, 2 and 3) and one more in an adjacent temporary pond or daya (4). 
occasionally to dry out (Serrano et al., 2006). Data from several sites in the southern marshland of the Doñana National Park (Fig. 3) was also used for comparison (Espinar, 2000; Espinar and Serrano, 2009). The Doñana National Park was entered onto the Ramsar list in 1982. In contrast to the Merja Sidi Boughaba, a large part of the original woodland forest has been lost from the Doñana dunes: vestiges of the original vegetation are now mixed with Pinus pinea, which has been extensively planted since the first quarter of the $17^{\text {th }}$ century to prevent the dunes advancing after deforestation (García-Novo and Marín, 2006).

\section{Climate}

Both areas are subject to a Mediterranean climate with Atlantic influence ensuring a yearly rainfall of about 500-600 $\mathrm{mm}$. The Mediterranean climate is characterised by hot dry summers, mild winters and a very variable amount of rainfall from year to year, although there is one certainty: the potential evapotranspiration will exceed rainfall during each and every summer. In Europe, this type of climate is not confined to the coastal land adjacent to the Mediterranean sea as it extends from Portugal to the south of the Caspian sea (Bolle, 2003). In North-West Morocco and South-West Spain, the Mediterranean climate is influenced by the production by the Atlantic ocean of a sub-humid Mediterranean climate with mild, moist winters from October until March/April, and hot, dry summers from May until September. In recent decades, average monthly temperatures have ranged from 5 to $32^{\circ} \mathrm{C}$ in the Doñana National Park, and from 7 to $28^{\circ} \mathrm{C}$ in the Moroccan town of Mehdia (Cherkauoi and Bouchafra, 2003).

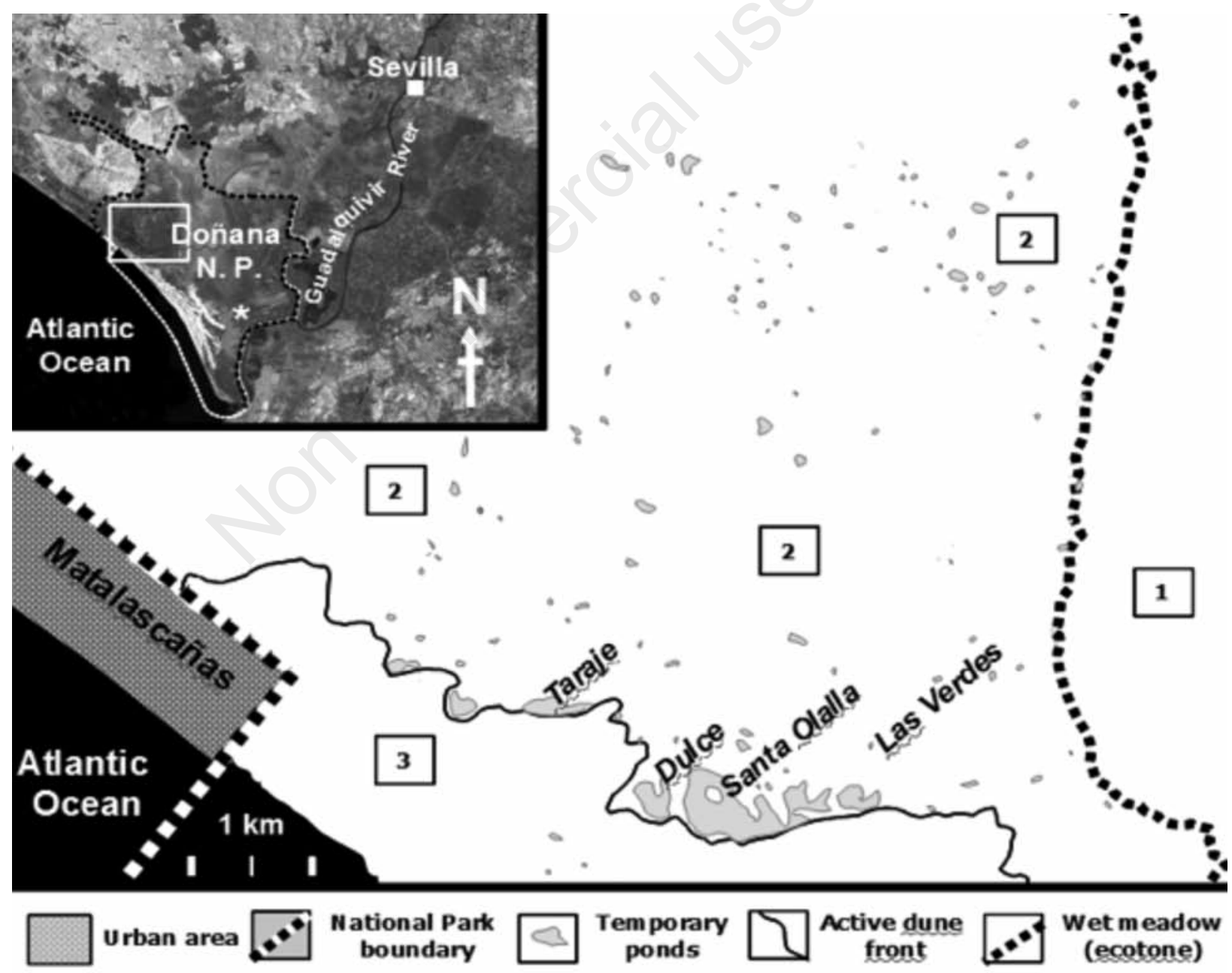

Fig. 3. The locations of those ponds and marshes in Doñana National Park (South-West Spain) that were used for comparison in this study (i.e. Taraje, Dulce, Santa Olalla, and Las Verdes), and the main landscapes in the area [i.e. marshland (1), stable sand dunes (2) and mobile or active sand dunes (3)]. The location of the southern marshland sites is denoted by an asterisk in the upper left box. 


\section{Sampling methods}

Four seasonal samplings were carried out in February, April, June and September 2009 at four stations within the Merja Sidi Boughaba: stations 1 to 3 were located by the shores of the merja from south to north, while station 4 was located in a small temporary pond (or daya) on the upper northern side of the National Natural Reserve of Sidi Boughaba (Fig. 2). The following variables were measured in situ: water depth, temperature, electrical conductivity (compensated at $25^{\circ} \mathrm{C}$ ), water turbidity (in FTU), $\mathrm{pH}$ and dissolved oxygen concentration. Water samples were collected from the surface in duplicate and a volume of 0.120-0.250 L was filtered in situ through Whatman GF/C filters for the analysis of dissolved substances: the filters were placed in sealed test tubes and kept in the dark. In the laboratory, the concentration of planktonic chlorophyll $a$ was extracted with methanol at $4^{\circ} \mathrm{C}$ for $24-$ $48 \mathrm{~h}$ (Talling and Driver, 1963). The dissolved water colour of filtered samples $\left(\mathrm{A}_{440}\right)$ was measured as the ratio of light absorbance at $440 \mathrm{~nm}$ to cell path length $\left(\mathrm{m}^{-1}\right)$ with a Hitachi U-2000 spectrophotometer (Hitachi Ltd., Tokyo, Japan) at ambient pH (Kirk, 1983). The concentration of i-P was determined following the method of Murphy and Riley (1962) and Tot-P was analysed as i-P after acid digestion of the unfiltered water sample (Golterman, 2004). The concentration of dissolved inorganic nitrogen (DIN) was determined colourimetrically as $\mathrm{NH}_{4}{ }^{+}$ after complete oxidation with $\mathrm{TiCl}_{3}$ (Golterman, 2004). The concentrations of $\mathrm{Na}^{+}, \mathrm{K}^{+}, \mathrm{Mg}^{2+}$ and $\mathrm{Ca}^{2+}$ were analysed by flame photometry. Ionic ratios were compared in meq $\mathrm{L}^{-1}$. Surface sediment samples were also collected at each sampling station in February, April and September for the determination of $\mathrm{pH}$, organic matter (loss-on-ignition at $450^{\circ} \mathrm{C}, 5 \mathrm{~h}$ ) and Tot-P (as i-P) after acid digestion of the ignited samples, and phosphorus fractions in the sediment were analysed in September following the EDTA-method (Golterman, 2004). Aquatic macrophytes were surveyed along one transect at each sampling station. Occasionally, plant samples were taken by hand and fixed with a modified Kew's mix $(65 \%$ ethanol, $5 \%$ glycerine, and $30 \% \mathrm{H}_{2} \mathrm{O}$ ) for identification of species in the laboratory. Additionally, the Taraje pond in the Doñana National Park was sampled in April 2009 for determining ionic concentrations in the same way as described above.

\section{Data analyses}

Spearman's rank order correlations were performed on untransformed variables and normality was checked using the Shapiro-Wilk test (Systat Software, Inc., Chicago, IL, USA). Multivariate analyses were carried out using the software PRIMER v.6. In order to perform a principal component analysis (PCA), variables were standardised and log-transformed, when needed, to ensure normality. A multivariate non-parametric analysis (BEST) was used to find the best match between the macrophyte assemblage and the environmental variables associated with those samples: the similarity matrix for the presence or absence of macrophytes was calculated using the BrayCurtis index, the environmental variables were standardised and normalised, and the Spearman's rank correlation method was used for matching. A non-parametric multivariate form of the classification and regression tree analyses (LINKTREE) was performed to determine the specific range values of the environmental data that appeared to be responsible for discriminating different groupings within the macrophyte assemblage.

\section{RESULTS}

The water was brackish at all sampling stations in Merja Sidi Boughaba during the study period: electrical conductivity in the water ranged from 5 to $14 \mathrm{mS} \cdot \mathrm{cm}^{-1}$ and was highest in June at station 1; a few weeks before this, the southern shoreside dried up, whereas water in the daya (station 4) was always fresher as the electrical conductivity ranged from 0.3 to $2.0 \mathrm{mS} \mathrm{cm}$ (Tab. 1). $\mathrm{Na}^{2+}$ was the dominant dissolved cation and the ratio between divalent and monovalent cations was always low. $\mathrm{Mg}^{2+}$ always dominated over $\mathrm{Ca}^{2+}$ in the Merja Sidi Boughaba, whereas $\mathrm{Ca}^{2+}$ equalled $\mathrm{Na}^{2+}$ and dominated over $\mathrm{Mg}^{2+}$ in the daya (station 4) during a rainy period in September when it started to refill after summer drought (Tab. 1). The pond of Taraje in the Doñana National Park, with an electrical conductivity of $4 \mathrm{mS} \mathrm{cm}^{-1}$ in April 2009, showed similar ionic ratios to those found in the Merja Sidi Boughaba at the same time, as the ratio for $\mathrm{Na}^{+} / \mathrm{Ca}^{2+}$ was 3.1, for $\mathrm{Na}^{+} / \mathrm{Mg}^{2+}$ was 2.0 and for $\mathrm{Mg}^{2+} / \mathrm{Ca}^{2+}$ was 1.6.

Turbidity was particularly high at sampling stations 1 (merja) and 4 (daya). The sediment was easily resuspended by the wind due to the shallow depth and higher proportion of inorganic material at these sites. In deeper sampling stations 2 and 3, the concentration of dissolved oxygen in the water was low, particularly near the bottom in February, April and June (Tab. 1). Total phosphorus concentrations in the water were mainly locked up in the particulate fraction, except at the daya (station 4) in June and September, when the highest concentrations of both Tot-P and i-P were found. The concentration of DIN ranged widely but was usually below $0.1 \mathrm{mM}$ (rarely reaching $0.4 \mathrm{mM}$ ).

As expected in shallow water bodies, there was a high variability of environmental factors and many variables cross-correlated with each other during the study period (Tab. 2). The depths of the sampling sites were inversely correlated with both the turbidity and the concentration of Tot-P in the water. The length of the wet phase prior to sampling at each site (or flooded period) was directly cor- 
related with the percentage of organic matter in the sediment, with the concentration of DIN and $\mathrm{NH}_{4}{ }^{+}$, and with the ratio of $\mathrm{Na}^{+} / \mathrm{Mg}^{2+}$ in the water (Tab. 2). This interplay between hydrological and limnological variables might also explain the observed inverse relationship between electrical conductivity and both the concentration of Tot$\mathrm{P}$ and i-P in the water (Tab. 2), as the dilution effect of the solutes that took place after the first autumn rainfall in September was probably coincident with an allochthonous P-input through runoff. The relevance of fluctuations in water level to the limnology of this shallow water system is also exemplified by the strong contribution of depth in a PCA ordination analysis that grouped $86.4 \%$ of variation in two axes combining water depth, turbidity, DIN concentration and the ratio of $\mathrm{Na}^{+} / \mathrm{Mg}^{2+}$ (Tab. 3).

The Merja Sidi Boughaba showed high values of planktonic biomass, estimated from the concentration of chlorophyll $a$, but also presented a rich community of submerged macrophyte species: Chara canescens, Chara aspera,
Chara (C.) galioides, Chara connivens, Tolypella (T.) glomerata, Ruppia (R.) cirrhosa, Zannichellia (Z.) palustris and Naias (N.) marina (Tab. 1). The wide spectrum of environmental conditions in the merja (plus the adjacent daya) may explain this high number of macrophyte species, as the water and sediment features changed from the northern side, with humic-coloured waters and a sandy substrate, to a calcium-rich substrate with turbid and silted waters at its southern side (Tab. 1). In fact, turbidity $(\mathrm{R}=0.512$, $\mathrm{P}<0.05)$ and dissolved water colour $(\mathrm{R}=0.400, \mathrm{P}<0.05)$ were the two variables that overall best correlated with the presence or absence of submerged macrophytes, according to a BEST analysis. A LINKTREE analysis based on the composition of submerged macrophytes in terms of presence or absence established several significant environmental thresholds $(\mathrm{R} \geq 0.500, \mathrm{P}<0.05)$ for the occurrence of some species. Most notably, Z. palustris and N. marina were both associated with very low turbidities $(<7 \mathrm{FTU})$ compared to the other species, but the former had a $\mathrm{Ca}^{2+}$

Tab. 1. Seasonal ranges of some limnological variables and list of submerged macrophyte species detected at each sampling station during the study period (February, April, June and September 2009).

\begin{tabular}{|c|c|c|c|c|}
\hline \multirow{2}{*}{ Variable or species } & \multicolumn{3}{|l|}{ Merja } & \multirow{2}{*}{$\begin{array}{c}\text { Daya } \\
4\end{array}$} \\
\hline & 1 & 2 & 3 & \\
\hline Water depth $(\mathrm{cm})$ & $0-30$ & $30-65$ & $15-60$ & $0-40$ \\
\hline Conductivity $\left(\mathrm{mS} \cdot \mathrm{cm}^{-1}\right)$ & $6.5-14.2$ & $10.8-13.7$ & $5.0-11.9$ & $0.3-2.0$ \\
\hline $\mathrm{Na}^{+}($meq L L $)$ & $25.7-101.6$ & $55.9-81.9$ & $22.1-100.7$ & $0.8-15.8$ \\
\hline $\mathrm{Mg}^{2+}\left(\mathrm{meq} \mathrm{L}^{-1}\right)$ & $12.3-28.4$ & $15.9-21.8$ & $8.8-29.5$ & $0.4-6.4$ \\
\hline $\mathrm{Ca}^{2+}\left(\mathrm{meq} \mathrm{L}^{-1}\right)$ & $4.2-7.5$ & $3.2-4.7$ & $1.3-2.9$ & $0.8-1.2$ \\
\hline $\mathrm{K}^{+}\left(\right.$meq L L $\left.^{-1}\right)$ & $0.9-3.1$ & $1.5-2.6$ & $0.9-3.1$ & $0.3-1.3$ \\
\hline $\mathrm{Na}^{+} / \mathrm{Ca}^{2+}$ & $4-24$ & $16-20$ & $10-35$ & $1-20$ \\
\hline $\mathrm{Mg}^{2+} / \mathrm{Ca}^{2+}$ & $1.8-6.7$ & $4.2-5.3$ & $4.5-10.3$ & $0.6-8.0$ \\
\hline $\mathrm{Na}^{+} / \mathrm{Mg}^{2+}$ & $2.1-3.6$ & $2.2-3.4$ & $3.4-3.8$ & $0.7-2.5$ \\
\hline Turbidity (FTU) & $31.0-45.4$ & $3.6-36.5$ & $7.3-32.6$ & $15.3-298$ \\
\hline $\mathrm{A}_{440}\left(\mathrm{~m}^{-1}\right)$ & $1.7-5.9$ & $1.7-4.7$ & $8.1-20.8$ & $0.1-9.7$ \\
\hline Water $\mathrm{pH}$ & $8.5-9.4$ & $7.6-7.8$ & $7.8-8.2$ & $8.5-8.9$ \\
\hline Sediment $\mathrm{pH}$ & $8.4-9.5$ & $7.5-7.8$ & $7.7-8.7$ & $8.4-8.9$ \\
\hline $\mathrm{O}_{2}\left(\mathrm{mg} \mathrm{L}^{-1}\right)$ & $6.4-15.4$ & $0.0-2.8$ & $0.0-4.4$ & $3.5-10.5$ \\
\hline Tot-P water $(\mu \mathrm{M})$ & $1.5-5.2$ & $1.3-11.6$ & $5.3-9.1$ & $8.3-25.2$ \\
\hline$P_{i}(\mu M)$ & $0.3-0.3$ & $0.0-2.4$ & $1.5-1.9$ & $5.6-7.9$ \\
\hline i-P/Tot-P (\%) & $9-21$ & $21-31$ & $0-21$ & $24-67$ \\
\hline $\mathrm{DIN}(\mu \mathrm{M})$ & $4.7-88.0$ & $1.8-391.6$ & $43.3-231.0$ & $1.8-360.8$ \\
\hline Chl $a\left(\mu \mathrm{g} \mathrm{L}^{-1}\right)$ & $1.3-68.9$ & $7.1-127.4$ & $3.6-28.3$ & $3.2-48.9$ \\
\hline Tot-P sediment ( $\mathrm{mg} \mathrm{g}^{-1}$ d.w.) & $0.4-1.0$ & $1.8-3.1$ & $0.4-1.0$ & $0.5-1.3$ \\
\hline O.M. (\%) & $5.3-7.9$ & $28.6-42.3$ & $2.8-14.2$ & $3.7-4.1$ \\
\hline $\mathrm{CaCO}_{3}$ bound to $\mathrm{P}(\%)$ & 75 & 60 & 47 & 71 \\
\hline Organic P-fractions $(\%)$ & 19 & 31 & 32 & 9 \\
\hline Chara canescens & $\mathrm{x}$ & & $\mathrm{x}$ & $\mathrm{x}$ \\
\hline Chara aspera & $\mathrm{x}$ & $\mathrm{x}$ & $\hat{x}$ & x \\
\hline Chara galioides & $\mathrm{x}$ & & $\mathrm{x}$ & \\
\hline Chara connivens & $\mathrm{x}$ & & & \\
\hline Tolypella glomerata & $\mathrm{x}$ & & & \\
\hline Ruppia cirrhosa & $\mathrm{x}$ & & & $\mathrm{x}$ \\
\hline Zannichellia palustris & & & $\mathrm{x}$ & \\
\hline Naias marina & & $\mathrm{x}$ & & \\
\hline
\end{tabular}

$A_{440}$, dissolved water colour of filtered samples; Tot-P, total phosphorus; $i-P / T o t-P$, ratio of dissolved inorganic phosphate concentration over Tot-P in the water; DIN, dissolved inorganic nitrogen; Chl a, chlorophyll a; O.M., organic matter concentration; P, phosphorus. 
concentration lower than 3.2 meq $\mathrm{L}^{-1}$ in comparison with the latter. T. glomerata was also distinctly associated to sites with some turbidity ( $>7$ FTU) and low $\mathrm{Na}^{+} / \mathrm{Ca}^{2+}$ ratios $(<5.8)$, while $R$. cirrhosa and $C$. galioides occurred at sites with some turbidity ( $>7 \mathrm{FTU}$ ) and very high $\mathrm{Na}^{+} / \mathrm{Ca}^{2+}$ ratios $(>19.7)$. In contrast, $C$. canescens appeared at sites with some turbidity ( $>7$ FTU) both in the merja and the daya from February to June, thus tolerating a wide range of environmental conditions.

\section{DISCUSSION}

A review of recent past conditions in the Merja Sidi Boughaba during a seasonal sampling in 1997-1999 (Fahti et al., 2001) is provided for comparison with the published data from some of the ponds and several sites within the marshland of the Doñana National Park (Tab. 4). The wide spectrum of environmental conditions found in the Merja Sidi Boughaba was also found in the Doñana ponds in combination with the silty-clay floodplain of the Doñana marshland. Other coastal dune areas in South-West Iberia, such as the sandy spits of El Rompido (South-West Spain) and the Ria Formosa Natural Park (South Portugal), have a different tectonic origin and their aeolian sand formations are not as extensive (Rodríguez, 2006). Moreover, dune ponds in the Doñana National Park (South-West Spain) have no Atlantic counterpart in Europe, although very extensive coastal dune areas also exist in The Netherlands and Denmark (Serrano and Toja, 1995). In contrast, these southern Mediterranean sites in North-West Morocco and South-West Spain shared wide seasonal ranges for key limnological variables, such as chorophyll and phosphorus concentrations (Tab. 4). Compared to the marshlands, the Doñana ponds exhibited lower electrical conductivities, $\mathrm{Na}^{+} / \mathrm{Ca}^{2+}$ ratios, i-P concentrations and a slightly acidic or circumneutral pH (Espinar and Serrano, 2009). Similarly to the merja at sites 2 and 3 (Tabs. 1 and 4), P in the sediment of the Doñana ponds was basically locked up in the organic fraction, although its bioavailability was controlled by the fraction of Fe bound to P (Serrano et al., 2006). The higher $\mathrm{pH}$ and concentration of $\mathrm{Ca}^{2+}$ in the sediment of the merja at site 1 suggested a strong binding capacity of $\mathrm{P}$ in the sediment (either deposited at the bottom or suspended due to wind action), which was dominated by the fraction of $\mathrm{CaCO}_{3}$ bound to $\mathrm{P}$, similar to the situation in the Doñana marshland (Reina et al., 2006). The range of organic matter concentration in the sediment of the Merja Sidi Boughaba was wider than in the Doñana ponds (Tab. 4), although up to $42.5 \%$ has been previously reported (Serrano, 1992). The highest concentration of organic matter (42\%) in the Merja Sidi Boughaba was associated with an area of extensive growth of Typha angustifolia, similarly to how higher concentrations of sediment organic matter have been associated with the presence of large emergent macrophytes in the Doñana marshland (Espinar et al., 2002; Reina et al., 2006). This large accumulation of organic matter in the sediment is indicative of highly productive systems, as expected for a shallow water body such as this with a permanent or semi-permanent regime that receives very high solar irradiance: the annual mean for global radiation in these southern Mediterranean sites is about $1750-1850 \mathrm{~kW} \mathrm{~h} \mathrm{~m}^{-2}$, while this value is almost half for the coastal dunes of The Netherlands or Denmark (www.meteonorm.com).

The higher proportion of $\mathrm{Mg}^{2+}$ over $\mathrm{Ca}^{2+}$ has separated the Doñana ponds from the other sodium-dominated waters in Spain, as recorded in an extensive survey of over 2000 shallow water bodies (Alonso, 1998). In view of the lack of easily soluble or hydrolysable minerals in these aeolian sands, the origin of $\mathrm{Mg}^{2+}$ in the shallow water table of Doñana can be explained by the influence of sea spray on the local rainfall, which has recharged the

Tab. 2. Spearman's rank order correlation coefficients among environmental variables in the study sites of the merja catchment.

\begin{tabular}{|c|c|c|c|c|c|c|c|c|c|c|}
\hline & Depth & $\mathrm{Na} / \mathrm{Mg}$ & TotP & i-P & PartP & i-P/TotP & DIN & $\mathrm{NH}_{4}^{+}$ & Chl $a$ & O.M. \\
\hline FTU & $-.788^{* *}$ & & $.573^{*}$ & & $.624^{*}$ & & & & $-.561^{*}$ & \\
\hline Flood & & $.546^{*}$ & & & & & $.808^{* *}$ & $.613^{*}$ & & $.737^{*}$ \\
\hline Depth & - & & $-.541^{*}$ & & & & & & & \\
\hline ATC & & $.868^{* *}$ & $-.621^{*}$ & $-.718^{*}$ & & $.664^{*}$ & & & $.611^{*}$ & $.733 \mathrm{v}$ \\
\hline $\mathrm{Na} / \mathrm{Mg}$ & & - & & $-.600^{*}$ & & $.809^{* *}$ & & & $.597^{*}$ & $.818^{* *}$ \\
\hline TotP & & & - & $.900^{* *}$ & $.945^{* *}$ & & & & & \\
\hline i-P & & & & - & $.773^{* *}$ & $-.745^{* *}$ & & & & \\
\hline PartP & & & & & - & & & & & \\
\hline i-P/TotP & & & & & & - & & & & $.709 \mathrm{v}$ \\
\hline DIN & & & & & & & - & $.692^{*}$ & & \\
\hline
\end{tabular}

Depth, depth at sampling; $\mathrm{Na} / \mathrm{Mg}$, ratio $\mathrm{Na}^{+} / \mathrm{Mg}^{2+}$; Tot-P, total phosphorus concentration in the water; $i-P$, dissolved inorganic phosphate concentration; partP, particulate-phosphorus concentration; $i$-P/TotP, ratio of $i$-P over Tot-P in the water; DIN, dissolved inorganic nitrogen; $\mathrm{NH}_{4}^{+}$, ammonium concentration; Chl a, planktonic chlorophyll a concentration; O.M., organic matter concentration; FTU, turbidity; flood, length of wet phase; ATC, conductivity. ${ }^{*} P<0.05,{ }^{* *} P<0.01$. 
groundwater over time (Lozano, 2004). The chemical composition of the unconfined aquifer is generally dominated by calcium bicarbonate, and the total salinity is lower than $0.5 \mathrm{mg} \mathrm{L}^{-1}$ (Llamas, 1990), except at pond discharge areas. Here, the effect of evaporative concentration has produced a sodium chloride or sodium bicarbonate shallow groundwater that becomes gradually depleted in $\mathrm{Ca}^{2+}$ and, to a lesser extent, $\mathrm{Mg}^{2+}$, due to calcite precipitation as the pond water remains exposed to further evaporative concentrations on the surface (Sacks et al., 1992). We proposed a similar mechanism for the dominance of $\mathrm{Mg}^{2+}$ over $\mathrm{Ca}^{2+}$ in the Merja Sidi Boughaba, where coastal sand dunes have a similar age and climate to those in the Doñana region. The significance of $\mathrm{Mg}^{2+}$ in these brackish sodium-dominated waters is also reported by Cherkaoui and Bouchafra (2003), although it is not recorded in other studies (Fathi et al., 2001).

The daya (site 4) adjacent to this merja has also been reported to be seasonal and oligohaline (Elkhiati et al., 2004), probably because it is basically fed by rainwater and runoff and, to a lesser extent, by the discharge of the water table during very wet years due to its slightly higher altitude compared to the merja. Its closer location to the town of Mehdia and smaller water volume suggests a higher anthropogenic influence than in the merja (sites 1, 2 and 3). The influence of bird droppings on nutrient lake budgets is minor given that anthropogenic sources of allochthonous nutrients are significant, although it can have a local effect in small lakes with very large bird population densities (Hahn et al., 2008). Waterbirds, however, tend to concentrate on the western shoreside of the merja where vegetation is more dense (Green et al., 2002). Therefore, agricultural runoff and urban waste water seepage arriving from the nearby town of Mehdia probably affected the daya, for which the woodland cover is lower than in the merja (Fig. 2). The concentration of i-P was consistently higher in site 4 and reached a maximum in February $(7.9 \mu \mathrm{M})$, while the proportion of i-P over Tot$P$ was as high as $67 \%$ in spring 2009. In contrast, this proportion was relatively low within the merja, both at the northern end, with clear but humic-coloured waters (site 3 ), and at the southern end, with highly silted waters (site 1). The adsorption of $P$ onto suspended silt particles

Tab. 3. Results of principal component ordination analysis: a) eigenvalues and cumulative percentage of variation explained by the first two axes; b) correlation between environmental variables and each of the two main axes.

\begin{tabular}{lcc}
\hline & Axis PCA1 & Axis PCA2 \\
\hline a) Eigenvalues & 2.1 & 1.45 \\
variation (\%) & 50.3 & 83.4 \\
b) Coefficients & & \\
Depth & 0.68 & 0.139 \\
DIN & -0.152 & -0.750 \\
FTU & -0.645 & 0.006 \\
$\mathrm{Na}^{+} / \mathrm{Mg}^{2+}$ & 0.317 & -0.646 \\
\hline
\end{tabular}

PCA1, first principal component; PCA2, second principal component; depth, depth at sampling; DIN, dissolved inorganic nitrogen; FTU, turbidity.

Tab. 4. Ranges of several limnological variables in the Merja Sidi Boughaba during our seasonal study (2009) and in previous seasonal studies (1997-1999), as well as in ponds and marshes of the Doñana National Park throughout the spring of 1996, 1997 and 1998, and the autumn of 1997,1998 and 1999.

\begin{tabular}{|c|c|c|c|c|}
\hline \multirow[t]{2}{*}{ Variables } & \multicolumn{2}{|c|}{$\begin{array}{l}\text { Merja Sidi } \\
\text { Boughaba }\end{array}$} & \multirow{2}{*}{$\begin{array}{c}\text { Doñana } \\
\text { ponds }^{\#} \\
(1996-1999)\end{array}$} & \multirow{2}{*}{$\begin{array}{c}\text { Doñana } \\
\text { marshes }^{\S} \\
(1996-1997)\end{array}$} \\
\hline & (2009) & $(1997-1999)^{\circ}$ & & \\
\hline Water depth $(\mathrm{m})$ & - & $1.6-2.3$ & $0.0-2.8$ & $0.0-0.6$ \\
\hline Conductivity $\left.(\mathrm{mS} \mathrm{cm})^{-1}\right)$ & $5.0-14.2$ & - & $0.3-11.6$ & $2.1-35.9$ \\
\hline T.D.S. $\left(\mathrm{g} \mathrm{L}^{-1}\right)$ & - & $0.7-11.5$ & - & - \\
\hline Water $\mathrm{pH}$ & 7.6-9.4 & $7.8-8.9$ & $6.2-8.3$ & $7.5-12.0$ \\
\hline Sediment $\mathrm{pH}$ & $7.5-9.5$ & - & $5.6-6.4$ & - \\
\hline O.M. (\%) & $2.8-42.3$ & - & $9.0-25.6$ & $3.5-14.2$ \\
\hline Alkalinity (meq L ${ }^{-1}$ ) & - & $1.8-9.3$ & $1.0-3.2$ & 1.6-6.1 \\
\hline $\mathrm{Na}^{+}\left(\right.$meq L $\left.{ }^{-1}\right)$ & $22.1-101.6$ & $102.2-176.5$ & $1.4-5.7$ & $32.7-546.4$ \\
\hline $\mathrm{Ca}^{2+}($ meq L L $)$ & $1.3-7.5$ & $2.7-4.0$ & $0.5-2.4$ & $1.6-15.8$ \\
\hline Tot-P $(\mu \mathrm{M})$ & $1.3-11.6$ & $4.5-31.8$ & $2.9-18.3$ & - \\
\hline$P_{i}(\mu \mathrm{M})$ & $0.0-2.4$ & $2.9-6.8$ & $0.0-3.3$ & $0.0-3.8$ \\
\hline i-P/Tot-P (\%) & $0-31$ & - & $1.0-18$ & - \\
\hline $\mathrm{NO}_{3}^{-}(\mu \mathrm{M})$ & $0.0-338.8$ & $21.4-85.0$ & $0.0-21.7$ & $7.3-31.2$ \\
\hline Planktonic chl $a\left(\mu \mathrm{g} \mathrm{L}^{-1}\right)$ & $1.3-127.4$ & $5.7-15.0$ & $1.5-125.0$ & $1.1-147.1$ \\
\hline
\end{tabular}

T.D.S, total dissolved solids; O.M., organic matter concentration; Tot-P, total phosphorus concentration in the water; $i$-P/TotP, ratio of dissolved inorganic phosphate concentration over Tot-P in the water. ${ }^{\circ}$ Elkhiati et al. (2004), Fathi et al. (2001); " Serrano et al. (2003, 2006), Espinar and Serrano (2009); ${ }^{s}$ Espinar (2000). 
(Golterman, 2004) can explain the lack of a significant correlation $(\mathrm{P}>0.05)$ between the concentrations of Tot-P and planktonic chlorophyll in the water, while turbidity was significantly correlated with both Tot-P and particulate $\mathrm{P}$ concentrations.

Although both areas, in North-West Morocco and South-West Spain, possess a high protection status, they are not immune to environmental impacts. Whether protected or not, the quality of an aquatic system will reflect the quality of all the water draining through its whole watershed which either may or may not be entirely protected. Similar to the study daya (site 4), the north and North-Eastern edges of the Doñana marshland are much closer to urban areas than its southern side, and high ratios of i-P to Tot-P have been reported there (Serrano et al., 2006). In contrast, nutrient concentrations in the Doñana ponds cannot be traced back to a direct anthropogenic pollution source. Storm events can mobilise a relatively high concentration of i-P from the upland vegetation, which is then recycled within the pond catchment and, eventually, flushed out towards the marshland and downstream to the estuary during heavy floods (Serrano et al., 2006). Consequently, primary production ranges widely following flood and drought cycles due to the effect of evaporative concentration and flushing events. Planktonic chlorophyll $a$ concentrations have been reported to be well above $1 \mathrm{mg} \mathrm{L}^{-1}$ during cyanobacterial blooms (Serrano and Toja, 1995), although heavy floods can disrupt primary production and revert the pond to earlier successional stages favouring the growth of extensive submerged macrophyte beds (up to $450 \mathrm{~g}$ d.w. $\mathrm{m}^{-2}$; López et al., 1991), particularly during years of moderate rainfall when a shallow depth compensates for the light absorption of these humic-coloured waters (Serrano, 1994). From a temperate-lake perspective, it is difficult to comprehend that the very large concentrations of chlorophyll $a$ occasionally found in Doñana ponds during blooms are not the consequence of direct pollution but are, instead, driven by the secular rhythm of floods and droughts. The very low proportions of i-P over Tot-P, coupled with a high chlorophyll concentrations (Tab. 4), suggest that the available i-P is balanced by the phytoplankton uptake in Doñana ponds during the growth season. The huge dimensions of the Doñana aquifer (over $3400 \mathrm{~km}^{2}$ and up to $100 \mathrm{~m}$ in depth; Llamas, 1990) ensure that the groundwater input to these ponds remains free from significant external nutrient loads and, for most of these ponds, is still largely controlled by natural hydrological processes. The exception is represented by those ponds located less than $1 \mathrm{~km}$ away from the tourist resort of Matalascañas, for which the length of the wet period has been significantly reduced due to groundwater abstraction over the last decade (Serrano and Zunzunegui, 2008). The Mamora aquifer (North-West Morocco) covers a few hundred $\mathrm{km}^{2}$ and supplies water for several major cities (including Rabat and Kenitra) in a region with strong demographic and agricultural pressures (Zouhri et al., 2004). Sensitivity to hydrological conditions for the in-lake concentration of nutrients and its implications for longterm restoration in the Mediterranean region has also been addressed in the Mediterranean shallow Lake Pamvotis (Papastergiadou et al., 2010), while other authors have even considered fluctuating Mediterranean shallow systems as sentinel environments in long-term studies (Ludovisi and Gaino, 2010).

Despite some signs of anthropic eutrophication in the study site, the community of submerged macrophytes was relatively rich, particularly in charophytes, which grew on extensive beds at site 4 . Species with abundant seed banks, such as charophytes, are particularly favoured over vascular plants after drought events or during the early stages of autogenic succession; higher macrophyte species richness is expected at sites with recurrent drawdowns and intermediate nutrient levels (Bornette and Puijalon, 2011). Previous studies in this merja have also found Chara aspera var. brevispina, C. imperfecta, C. baltica and Lamprothamnium papulosum (Elkhiati et al., 2004). In Doñana, 17 species of submerged macrophytes, including five charophytes, were recorded in 21 ponds during 20062007 (Díaz-Paniagua et al., 2010). The macrophyte composition of the Doñana ponds lacked those species that are typical of highly mineralised water, although $L$. papulosum, Naias marina and Nitella hyalina occur in the Doñana marshland where $C$. galioides is also found at sites with very high $\mathrm{Na}^{+} / \mathrm{Ca}^{2+}$ ratios (Espinar, 2000), and where the rich macrophyte community (up to 21 species) is also dominated by charophytes (Espinar, 2006).

\section{CONCLUSIONS}

The EU Water Framework Directive recognises that the ecology of water bodies varies with climate and landscape and so there is no need for a trophic classification of shallow lakes but rather to establish indicators for good ecological status in the context of undisturbed reference conditions. Wetlands with the highest degree of environmental protection, such as the Doñana National Park in Spain, may achieve a poor (or even bad) status due to the misapplication of the thresholds developed for deep stratified lakes in order to estimate their trophic level (OECD, 1982). New tools are required for the assessment of the potential productivity of Mediterranean shallow lakes and wetlands with fluctuating water levels. The comparison between the Merja Sidi Boughaba and Doñana wetlands, which share a similar climate, location and palaeogeography, can help to discriminate natural eutrophy from anthropogenic eutrophication. These southern Mediterranean wetlands are naturally very productive aquatic systems in 
which both biomass uptake during the growth season and the binding capacity of the sediment (and resuspended silt) control the concentration of i-P in the water, according to the equilibrium model proposed by Golterman (2004). So far, these processes have been able to maintain a low availability of i-P in these wetlands, though there were probably some signs of anthropic stress in the daya located at the northern edge of the National Natural Reserve of Sidi Boughaba, where the proportion of i-P over Tot-P in the water was highest during the study period.

\section{ACKNOWLEDGMENTS}

This study was part of a research project supported by the Spanish Agency for International Cooperation (AECID-A/019949/08). Climate data in the Doñana National Park was provided by the Equipo de Seguimiento de Procesos Naturales de la Estación Biológica de Doñana. We are very thankful to Roger Flower for his critical review of an earlier version of this manuscript.

\section{REFERENCES}

Alonso M, 1998. [Las lagunas de la España Peninsular]. [Article in Spanish]. Limnetica 15:1-176.

Álvarez-Cobelas M, Rojo C, Angeler DG, 2005. Mediterranean limnology: current status, gaps and the future. Limnetica 64:13-29.

Barbieri R, Ori GG, 2000. Neogene palaeoenvironmental evolution in the Atlantic side of the Rifian Corridor (Morocco). Palaeogeogr. Palaeoecol. 163:1-31.

Bolle HJ, 2003. Mediterranean climate. Variability and trends. Springer Verlarg, Berlin: 372 pp.

Bornette G, Puijalon S, 2011. Response of aquatic plants to abiotic factors: a review. Aquat. Sci. 73:1-14.

Chergui H, Pattee E, Essafi K, Mhamdi MA, 1999. Moroccan limnology, p. 235-330. In: R.G. Wetzel, B. Gopal (eds.), Limnology in developing countries. 2. SIL International Association for Limnology Publ.

Cherkaoui I, Bouchafra A, 2003. [Fiche descriptive sur les zones humides Ramsar (FDR)]. [Book in French]. Wetlands International Publ. Available from: www.wetlands.org/reports/ ris/1MA002_RIS05fr.pdf

Crespo-Blanc A, Frizon de Lamotte D, 2006. Structural evolution of the external zones derived from the Flysch trough and the South Iberian and Maghrebian paleomargins around the Gibraltar arc: a comparative study. B. Soc. Géol. Fr. 177:267-282.

Díaz-Paniagua C, Fernández-Zamudio R, Florencio M, GarcíaMurillo P, Gómez-Rodríguez C, Portheault A, Serrano L, Siljeström P, 2010. Temporary ponds from Doñana National Park: a system of natural habitats for the preservation of aquatic flora and fauna. Limnetica 29:41-58.

Elkhiati N, Soulie-Märsche I, Gemayel P, Flower RJ, Ramdani M, 2004. Recent environmental changes at Sidi Bou Rhaba Lake (Morocco) inferred from fossil Charophyte gyrogonites. Cryptogamie Algol. 25:175-188.

Espinar JL, 2000. [Distribución espacial y temporal de las co- munidades de macrófitos acuáticos de la "Marisma salada" del Parque Nacional de Doñana]. [PhD Thesis in Spanish]. University of Sevilla ed., Sevilla: 126 pp.

Espinar JL, García LV, García-Murillo P, Toja J, 2002. Submerged macrophyte zonation in a Mediterranean salt marsh: a facilitation effect from established helophytes? J. Veg. Sci. 13:831-840.

Espinar JL, 2006. The importance of sample size for the detection of a biomass-diversity pattern in Mediterranean wetlands. J. Veg. Sci. 17:227-232.

Espinar JL, Serrano L, 2009. A quantitative hydrogeomorphic approach to the classification of temporary wetlands in the Doñana National Park (SW Spain). Aquat. Ecol. 43:323334.

Fathi AA, Abdelzaher HMA, Flower RJ, Ramdani M, Kraïem MM, 2001. Phytoplankton communities of North African wetland lakes: the CASSARINA Project. Aquat. Ecol. 35:303-318.

Flower RJ, 2001. Change, stress, sustainability and aquatic ecosystem resilience in North African wetland lakes during the 20th century: an introduction to integrated biodiversity studies within the CASSARINA Project. Aquat. Ecol. 35:261-280.

García-Novo F, Marín C, 2006. Doñana. Water and biosphere. Spanish Ministry of Environment Publ., Madrid: 366 pp.

Golterman HL, 2004. The chemistry of phosphate and nitrogen compounds in sediment. Kluwer Academic Publishers, Dordrecht: $251 \mathrm{pp}$.

Green AJ, El Hamzaoui M, El Agbani MA, Franchimont J, 2002. The conservation status of Moroccan wetlands with particular reference to waterbirds and to changes since 1978. Biol. Conserv. 104:71-82.

Hahn S, Bauer S, Klaassen M, 2008. Quantification of allochthonous nutrient inputbinto freshwater bodies by herbivorous waterbirds. Freshwater Biol. 53:181-193.

Horne AJ, Goldman CR, 1994. Limnology. McGraw-Hill, New York: $576 \mathrm{pp}$.

Kirk JTO, 1983. Light and photosynthesis in aquatic ecosystems. Cambridge University Press, Cambridge: $401 \mathrm{pp}$.

Llamas R, 1990. Geomorphology of the eolian sands of the Doñana National Park (Spain). Catena Supp. 18:145-154.

López T, Toja J, Gabellone NA, 1991. Limnological comparison of two peridunar ponds in the Doñana National Park (Spain). Arch. Hydrobiol. 120:357-378.

Lozano E, 2004. [Las aguas subterráneas en Los Cotos de Doñana y su influencia en las lagunas]. [PhD Thesis in Spanish]. Universidad Politécnica de Barcelona ed., Barcelona: 414 pp.

Ludovisi A, Gaino E, 2010. Meteorological and water quality changes in Lake Trasimeno (Umbria, Italy) during the last fifty years. J. Limnol. 69:174-188.

Moss B, Stephen D, Balayla D, Bécares E, Collings SE, Fernández-Aláez C, Fernández-Aláez M, Ferriol C, García P, Gomá J, Gyllström M, Hansson LA, Hietala J, Kairesalo T, Miracle MR, Romo S, Rueda S, Russell V, Ståhl-Delbanco A, Svennson M, Vakkilainen K, Valentin M, Van de Bund WJ, Van Donk E, Vicente E, Villena MJ, 2004. Continental-scale patterns of nutrient and fish effects on shallow wetland lakes: synthesis of a pan-European mesocosm experiment. Freshwater Biol. 49:1633-1650. 
Murphy J, Riley JP, 1962. A modified single solution method for the determination of soluble phosphate in natural waters. Anal. Chim. Acta 27:31-36.

OECD, 1982. Eutophication of waters: monitoring, assessment and control. Technical report. Organisation for Economic Co-operation and Development Publ., Paris: 164 pp.

Papastergiadou E, Kagalou I, Stephanidis K, Retalis A, Leonardos I, 2010. Effects of anthropogenic influences on the trophic state, land uses and aquatic vegetation in a shallow Mediterranean lake: implications for restoration. Water Resour. Manag. 24:415-435.

Ramdani M, Elkhiati N, Flower RJ, 2009. Lakes of Africa: North of Sahara, p. 544-554. In: G.E. Likens (ed.), Encyclopedia of inland waters. Academic Press.

Ramdani M, Flower RJ, Elkhiati N, Kraïem MM, Fathi AA, Birks HH, Patrick ST, 2001. North African wetland lakes: characterization of nine sites included in the CASSARINA Project. Aquat. Ecol. 35:281-302.

Reina M, Espinar JL, Serrano L, 2006. Sediment phosphate composition in relation to emergent macrophytes in the Doñana Marshes (SW Spain). Water Res. 40:1185-1190.

Rodríguez J, 2006. The geomorphological evolution of Doñana, p. 137-139. In: F. García-Novo, C. Marín (eds.), Doñana. Water and biosphere. Spanish Ministry of Environment Publ.

Rossaro B, Boggero A, Lencioni V, Marziali L, Solimni A, 2006. Tools for the development of a benthic quality index for Italian lakes. J. Limnol. 65:41-51.

Sacks LA, Herman JS, Konikow LF, Vela AL, 1992. Seasonal dynamics of groundwater-lake interactions at Doñana National Park, Spain. J. Hydrol. 136:123-154.

Serrano L, 1992. Leaching from vegetation of soluble polyphe- nolic compounds, and their abundance in temporary ponds in the Doñana National Park (SW Spain). Hydrobiologia 229:43-50.

Serrano L, 1994. Sources, abundance and disappearance of polyphenolic compounds in temporary ponds of Doñana National Park (South-western Spain). Aust. J. Mar. Fresh. Res. 45:1555-1564.

Serrano L, Calzada-Bujak I, Toja J, 2003. Variability of the sediment phosphate composition of a temporary pond (Doñana National Park, SW Spain). Hydrobiologia 429:159-169.

Serrano L, Reina M, Martín G, Reyes I, Arechederra A, León D, Toja J, 2006. The aquatic systems of Doñana (SW Spain): watersheds and frontiers. Limnetica 25:11-32.

Serrano L, Toja J, 1995. Limnological description of four temporary ponds in the Doñana National Park (SW, Spain). Arch. Hydrobiol. 133:497-516.

Serrano L, Zunzunegui M, 2008. The relevance of preserving temporary ponds during drought: hydrological and vegetation changes over a 16-year period in the Doñana National Park (south-west Spain). Aquat. Conserv. 18:261-279.

Søndergaard M, Jeppesen E, Jensen JP, Amsinck SL, 2005. Water framework directive: ecological classification of Danish lakes. J. Appl. Ecol. 42:616-629.

Talling JF, Driver D, 1963. Some problems in the estimation of chlorophyll-a in phytoplankton, p 142-146. In: Proc. Conf. Primary Productivity Measurements, Marine and Freshwaters. US Atomic Energy Commission TID-7633 Publ., Honolulu.

Zouhri L, Gorini C, Deffontaines B, Mania J, 2004. Relationships between hydraulic conductivity distribution and synsedimentary faults, Rharb-Mamora basin, Morocco; Hydrogeological, geostatistical and modeling approaches. Hydrogeol. J. 12:591-600. 